\title{
Battle lines shift in stem-cell funding fight...
}

Washington

A new strategy was introduced last week into the stormy debate on whether the US government should support research on human stem cells. A move was made to draw a sharp line between research on the embryonic and adult versions of the pluripotent cells.

There is broad agreement that stem cells could provide a range of valuable replacement parts, from insulin-producing islet cells to treat juvenile diabetes, to neural cells for treating neurodegenerative disorders such as amyotrophic lateral sclerosis (ALS), otherwise known as Lou Gehrig's disease.

But there is disagreement over the funding of stem-cell research. Some scientists and activists say that ethical quandary could be avoided by funding research using adult stem cells, but not embryonic stem cells. But others argue that limiting research to adult cells could prevent the field's therapeutic promise from being fully realized.

The ethical contention exists because deriving stem cells from embryos destroys them. The scientific conflict arises because many researchers think embryonic stem cells could be more useful than their adult counterparts. Embryonic stem cells can potentially

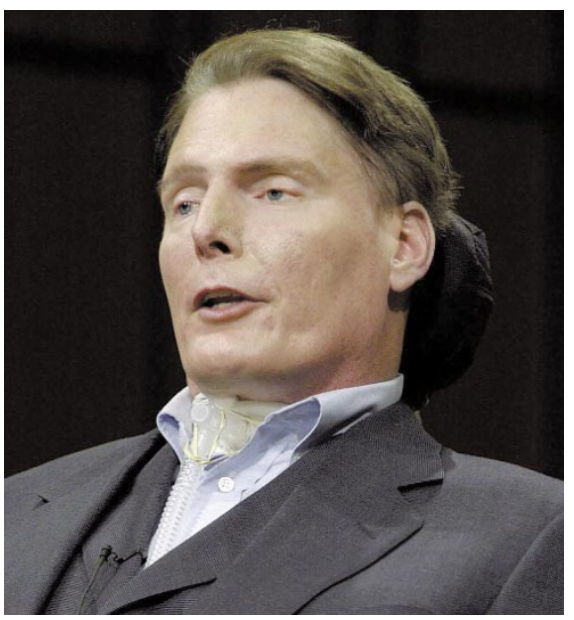

Reeve: told the committee that stem cells from discarded embryos should be used for research.

become many more types of cells, and may be able to divide for longer than adult stem cells.

Both ethical and scientific reasons for and against federal funding for embryonic stemcell research were aired at a Senate committee hearing last week that may have been a dress rehearsal for what Arlen Specter (Republican, Pennsylvania) promises to be "a knockdown, drag-out” fight in the Senate.

\section{... as non-profit companies enter the fray}

\section{Washington}

Industry and private foundations are taking the lead in stem-cell research, while Congress wrestles with legislation and researchers wait for revised guidelines from the US National Institutes of Health. But even though they don't face the tighter regulation and heightened scrutiny of federally funded research, private stem-cell backers are still finding that their efforts attract controversy.

The University of Wisconsin's technology transfer office, the Wisconsin Alumni Research Foundation (WARF), has set up a non-profit company to distribute embryonic stem cells isolated and grown by one of the university's researchers, James Thomson. His work was funded by a biotech company called Geron, based in Menlo Park, California.

According to WARF's managing director, Carl Gulbrandsen, the non-profit company, WiCell Research Institution, will begin distributing the cells in June, whether or not the NIH guidelines have been completed. If they have not been completed, he says, privately funded investigators will still have access to Thomson's embryonic stem cells, whereas publicly funded scientists will have to wait.

But the terms under which WiCell is making the cells available are likely to stir controversy - the company's material transfer agreement gives it the right to require that any cells not used for the purposes expressed in researchers' applications are destroyed.

The Wisconsin state legislature may also have an impact on the company. A bill to ban the sale or transfer of human tissue narrowly missed being put up for a vote during the most recent legislative term. The bill may re-emerge in the autumn.

Meanwhile, Project ALS, a New York-based non-profit institution, is also funding stem-cell research. So far, the research it pays for has involved only cells derived from aborted fetuses rather than from discarded embryos. Federal sources can now fund fetal tissue research, but not embryonic cell research.

The cells distributed by Project ALS have until now come from Layton BioScience of Sunnyvale, California. The company has exclusive licence on any commercial application that may result from research using its cell lines.

The Howard Hughes Medical Institute (HHMI) has formally begun considering funding stemcell research. In a meeting last month, the institute's leadership began to weigh the pros and cons of moving ahead, but has not yet come to a decision. "HHMI will consider in a deliberate manner how it ought to proceed in this potentially vital scientific research area, recognizing both the promise of the research and the ethical challenges it presents," says spokesman Robert Potter.
Specter and Tom Harkin (Democrat, Iowa) are backing a bill that would allow federal funding for both the derivation and use of embryonic stem cells. The bill, which Specter says will reach the Senate within the next month, represents just one battle in a war over stem-cell research. The US National Institutes of Health will soon issue revised guidelines that allow federal funding for the use, but not the derivation, of embryonic stem cells.

Meanwhile, private companies continue to conduct embryonic stem-cell research, unregulated by the government. And nonprofit organizations may soon increase their role in both the funding and distribution of stem cells (see below).

At last week's hearing, individuals who could benefit directly from embryonic stemcell research testified both for and against it. Mary Jane Owen, the executive director of the National Catholic Office for Persons with Disabilities, said she would rather not destroy an embryo to fix her damaged spinal cord. "We have alternatives," she said.

But the US actor Christopher Reeve, who was paralysed in an equestrian accident, said scientists should keep all avenues open. Reeve emphasized that excess embryos have long been discarded after in vitro fertilization attempts have ended. "Why has the use of discarded embryos for research suddenly become an issue?" Reeve asked.

Lawrence Goldstein, professor of cellular and molecular medicine at the University of California, emphasized the need to study many kinds of stem cells. Embryonic stem cells cultured by James Thomson at the University of Wisconsin, Madison, differ substantially from embryonic germ cells grown by John Gearhart at Johns Hopkins University, even though Gearhart's cells are only slightly more developed than Thomson's.

Even two different embryonic stem cell lines may behave differently, Goldstein said after the hearing. He added that allowing funding for deriving the cells is important because different extraction and culturing techniques could result in similar-seeming cells acting differently. "We probably need a bunch of different cell lines derived in a bunch of different ways," he said.

Having a wider variety of cell lines promotes better clinical science, says Jeff Rothstein, a neurology researcher at Johns Hopkins. But he adds that it will be important to fully characterize each cell line .

Rothstein is using stem cells from Gearhart, as well as neural stem cells derived from a fetus, to study cell therapy in ALS mouse models. He will soon examine adult progenitor cells in the same model. "We believe that only a comprehensive approach will be the best initial approach for a disease like ALS," he says. 